\title{
Deposition and retention of inhaled fibres: effects on incidence of lung cancer and mesothelioma
}

\author{
Morton Lippmann
}

\begin{abstract}
A review of the literature on chronic inhalation studies in which rats were exposed to mineral fibres at known fibre number concentrations was undertaken to examine the specific roles of fibre length and composition on the incidences of both lung cancer and mesothelioma. For lung cancer, the percentage of lung tumours ( $y$ ) could be described by a relation of the form $y=a+b f+c^{2}$, where $f$ is the concentration of fibre numbers and $a, b$, and $c$ are fitted constants. The correlation coefficients for the fitted curves were 0.76 for $>5 \mu \mathrm{m} \mathrm{f} / \mathrm{ml}, 0.84$ for $>10 \mu \mathrm{m}$ f $/ \mathrm{ml}$, and 0.85 for $>20 \mu \mathrm{m} f / \mathrm{ml}$. These seemed to be independent of fibre type. It has been shown that brief inhalation exposures to chrysotile fibre produces highly concentrated fibre deposits on bifurcations of alveolar ducts, and that many of these fibres are phagocytosed by the underlying type II epithelial cells within a few hours. Churg has shown that both chrysotile and amphibole fibres retained in the lungs of former miners and millers do not clear much with the years since last exposure. Thus, lung tumours may be caused by that small fraction of the inhaled fibres that are retained in the interstitium below small airway bifurcations where clearance processes are ineffective.
\end{abstract}

By contrast, for mesothelioma, the (low) tumour yields seemed to be highly dependent upon fibre type. Combining the data from various studies by fibre type, the percentage of mesotheliomas was $\mathbf{0 . 6 \%}$ for Zimbabwe (Rhodesian) chrysotile, $2 \cdot 5 \%$ for the various amphiboles as a group, and $4.7 \%$ for Quebec (Canadian) chrysotile. This difference, together with the fact that Zimbabwe chrysotile has 2 to 3 orders of magnitude less tremolite than Quebec chrysotile, provides support for the hypothesis that the mesotheliomas that have occurred among chrysotile miners and millers could be largely due to their exposures to tremolite fibres. The chrysotile fibres may be insufficiently biopersistent because of dissolution during translocation from their sites of deposition to sites where more durable fibres can influence the transformation or progression to mesothelioma.

(Occup Environ Med 1994;51:793-798)
Keywords: asbestos, lung cancer, mesothelioma.

All inhaled particles have non-uniform deposition patterns within lung airways. In the large airways, large particles (diameter $\geqslant 2$ $\mu \mathrm{m})$ deposit preferentially on airway bifurcations due to their momentum. ${ }^{1}$ In all airways and for all particle sizes, the greater concentration of high velocity streamlines of flow around bifurcations results in enhanced deposition on such surfaces. ${ }^{2}$ Furthermore, in small airways, the axial core flow in the distal direction that is superimposed on the tidal flow during multiple breathing cycles leads to preferential deposition on the bifurcations of small airways. ${ }^{34}$

Detailed information on particle deposition and the initial stages of translocation from the sites of deposition to other locations within the lungs and beyond has been obtained in studies in which laboratory animals were briefly exposed to airborne particles shortly before they were killed. Microscopic evaluation of airway sections collected by microdissection provided quantitative information about the distribution of particles on the surfaces of the fluid layers above the epithelial cells, as well as the distribution of particles on, within, and beyond the epithelial cells at the time of death. By killing laboratory animals at various times after the end of inhalation, one can characterise the distribution of retained particles at various anatomical sites as a function of time after the end of exposure. This can provide estimates of the kinetics of particle migration into and through the epithelium and along translocation pathways. Studies of local particle deposition and retention within the first day after particle inhalation have been performed at the respiratory acinus ${ }^{5-7}$ and within the trachea. ${ }^{8-10}$ The concentrations of particles in these laboratory studies were much higher than those encountered in occupational exposure, but the exposure duration was much shorter. Although interpretations of studies of high doses need to be made with caution, the microscopic assays performed in these studies show individually identifiable particles and fibres, and the translocation pathways found may well be applicable to comparable integral doses delivered over longer periods of time.

Brody and $\mathrm{Yu}$ provided a theoretical basis for the highly concentrated fibre deposition at alveolar duct bifurcations in the rat, and noted that the deposition pattern in humans, with highly developed respiratory bronchioles, may differ. ${ }^{11}$ On the other hand, they also 
noted that early pneumoconiotic lesions are found at the bronchoalveolar junctions in the lungs of humans.

Valuable information has also been found in human lungs obtained at necropsy, especially when a reliable history of occupational or environmental exposure to the airborne particles of interest was also available. ${ }^{12}{ }^{13}$ For long fibres (length $\geqslant 10 \mu \mathrm{m}$ ), there was a significant enhancement of bifurcation deposition due to the interception mechanism. ${ }^{14}$ Thus, there is preferential deposition of inhaled fibres at airway bifurcations through the combined actions of all of these mechanisms.

In this paper, I discuss the influence of fibre length, diameter, and durability of inhaled mineral fibres within the lungs on their retention times and clearance pathways in the lungs, and on their potency in the induction of lung cancer and mesothelioma. In comparison with shorter fibres and more compact mineral particles, fibres $\geqslant 10 \mu \mathrm{m}$ in length are retained to a greater extent within human lungs $^{12}$ and animal lungs. ${ }^{15-17}$ This is most likely due to the inability of lung macrophages (about $12 \mu \mathrm{m}$ diameter) to fully ingest the longer fibres. ${ }^{18}$ Fibre diameter can affect retention at the respiratory epithelium in a different way. Fibres $\leqslant 0.15 \mu \mathrm{m}$ in diameter seem to be able to pass through pores in the epithelial membrane. ${ }^{19}$ Similar penetration is achieved by compact particles of similar small diameters, such as $\mathrm{TiO}_{2}{ }^{20}$

For nominally insoluble fibres not cleared from the tracheobronchial airways by mucociliary transport, or from the gas exchange airways by macrophage mediated clearance through the tracheobronchial airways, their rates of dissolution within cells and interstitial fluids can be an important determinant of their pathogenic potential. The increasing rate of dissolution in lung fluid simulants, in which glass wool > rock wool $>$ chrysotile asbestos $>$ amphibole asbestos is well matched in reverse order of their abilities to produce cytotoxicity, lung fibrosis, and cancer. ${ }^{21}$

The differential lung clearance between fibres of chrysotile, a serpentine asbestos mineral, and the more rod like amphibole asbestos fibres, such as amosite, anthophyllite, crocidolite, and tremolite was shown for rats that underwent chronic inhalation exposures, by Wagner et al. ${ }^{22}$ Figure 1 shows that the lung fibre burdens of the amphiboles rose continuously throughout the two year exposure interval, and they declined slowly in the rats removed from exposure after six months. By contrast, the lung burdens in rats exposed to both Quebec and Zimbabwe chrysotile rose much more slowly during exposure, and seemed to decline after 12 months, even with further exposure.

Similar differential retention has been found in humans. Churg reported on analyses of lung tissue for 94 chrysotile asbestos miners and millers from the Thetford region of Quebec, Canada. ${ }^{13}$ The chrysotile deposit and exposure atmosphere contained a very small percentage of tremolite, yet the lungs contained more tremolite than chrysotile (fig 2),

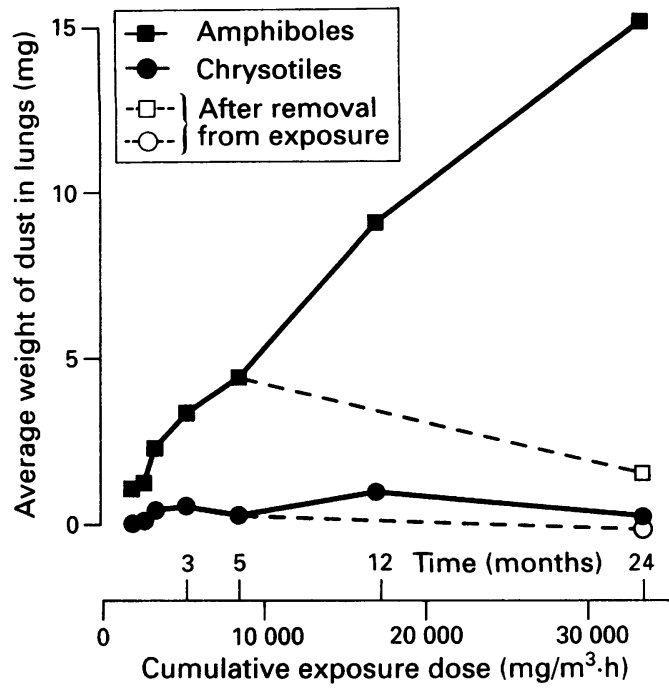

Figure 1 Mean weight of dust in lungs of rats in relation to cumulative exposure and duration of exposure time. Reproduced with permission from Wagner, et al. ${ }^{22}$

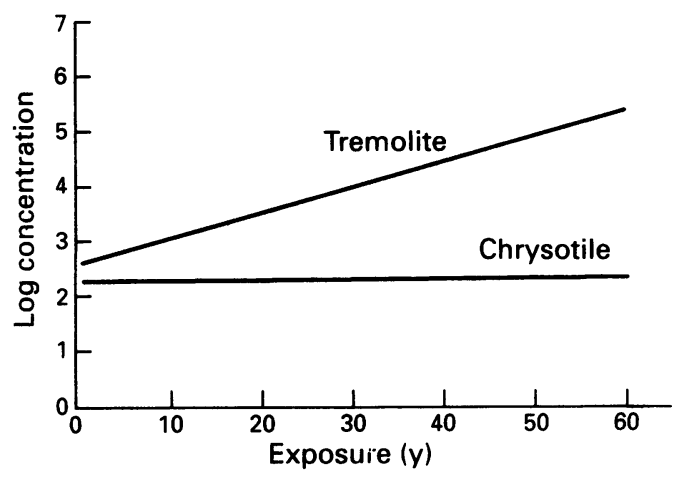

Figure 2 Predicted fibre concentration as a function of continuous years of occupational exposure based on analyses of lung retention of chrysotile and tremolite fibres for 94 miners and millers from the Thetford region of Quebec. Reproduced with permission from Churg. ${ }^{13}$

and the tremolite content increased rapidly with the duration of exposure.

Although most of the inhaled chrysotile was rapidly cleared from the lungs, a small fraction seemed to be retained indefinitely. Figure 3 shows that after exposure ends, there was little or no clearance of either chrysotile or tremolite from the lungs of the Thetford miners and millers.

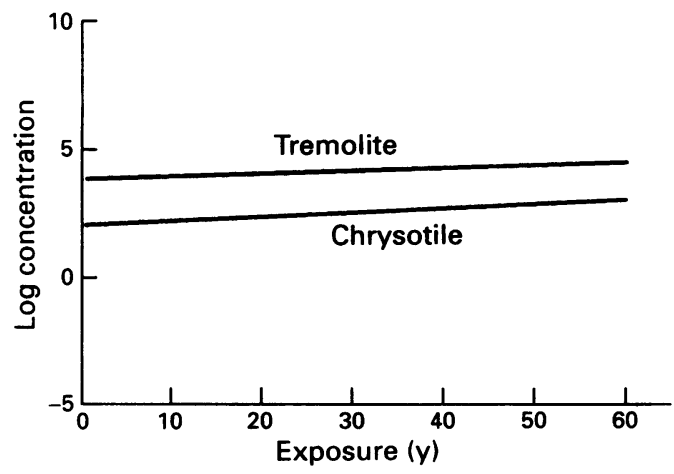

Figure 3 Predicted fibre concentration as a function of time since last exposure based on analyses of lung retention of chrysotile and tremolite fibres for 94 miners and millers from the Thetford region of Quebec. Reproduced with permission from Churg. ${ }^{13}$ 


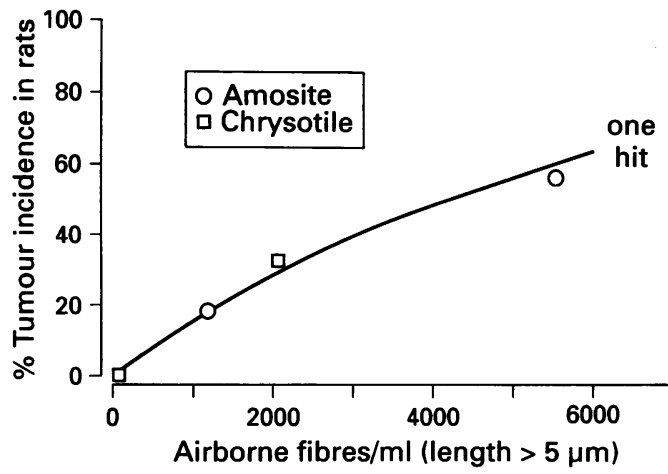

Figure 4 Total incidence of tumours (lung and mesothelial) in rats exposed by inhalation to long and short amosite by Davis et al ${ }^{25}$ and long and short chrysotile by Davis and fones ${ }^{26} v$ airborne concentration of fibres $>5$ $\mu \mathrm{m}$ in length, as presented by Pott. ${ }^{24}$ Reproduced with permission.

\section{Fibre deposition retention and lung cancer}

If most of the inhaled chrysotile fibres are rapidly cleared from the lung, but most of inhaled amphibole fibres are retained, then one would expect that the risk of lung cancer would be much greater for the amphiboles, assuming that fibre count and size were similar. It is not clear from human experience, ${ }^{23}$ or animal inhalation studies, that this is so. A recent paper by Pott, based on data from rat inhalation studies, performed by Davis and colleagues, ${ }^{25}{ }^{26}$ suggests that once normalised for the airborne concentration of fibres $\geqslant 5$ $\mu \mathrm{m}$ long, amosite and chrysotile are equivalent in potency (fig 4). ${ }^{24}$

To determine whether the alignment of the three positive points on fig 4 was fortuitous, I assembled the results of all of the available data from inhalation studies in which rats were exposed for $\geqslant 12$ months to mineral fibres (table 1). Whereas Pott had plotted both lung and mesothelial tumours in his figure, ${ }^{24}$ I restricted my examination to lung tumours on the basis that different mechanisms apply to risks of mesothelioma and lung

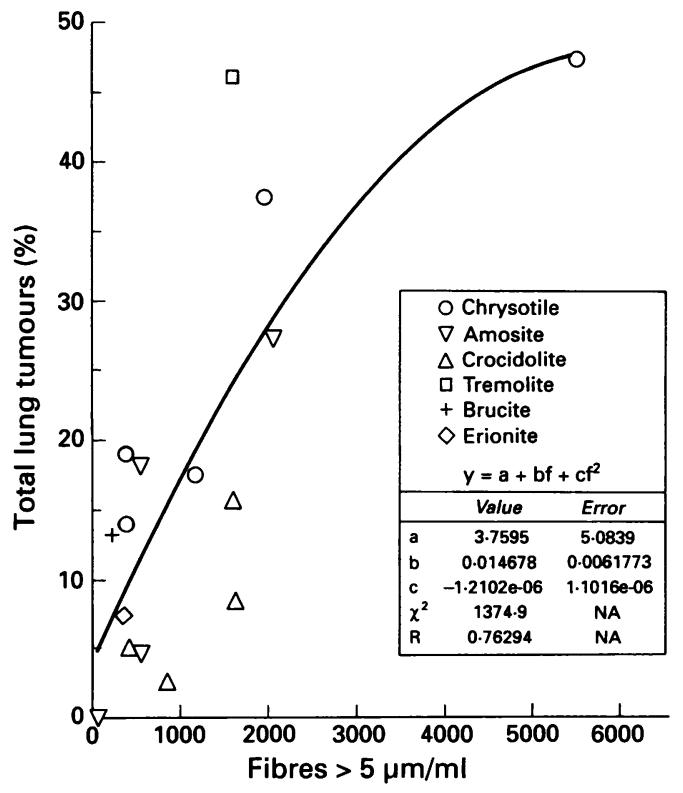

Figure 5 Total incidence of lung tumours in rats chronically exposed by inhalation to various mineral fibres as a function of the concentration of fibres $>5 \mu \mathrm{m}$ in length.

cancer. ${ }^{27}$ The data on airborne fibre concentration are those reported by the investigator, estimated by the original investigator for other cut off sizes based on their interpretations of the data on the distribution of fibre size, or estimated by me in a similar way. For the data of Davis et $a l^{252628-30}$ and Wagner et $a l^{31} 32$ the direct measurements of concentration were made by phase contrast optical microscopy, and the data on size distribution were obtained by scanning electron microscopy. McConnell's data were based on transmission electron microscopy.

Figures 5, 6, and 7 plot the data in table 1 . They show that the airborne concentrations of fibres $>5 \mu \mathrm{m}$ long (fig 5), $>10 \mu \mathrm{m}$ (fig 6) and $>20 \mu \mathrm{m}$ (fig 7) all indicate a clear and significant trend of increasing incidence of tumours with increasing exposures. The quadratic

Table 1 Summary of lung tumours in rats chronically exposed by inhalation

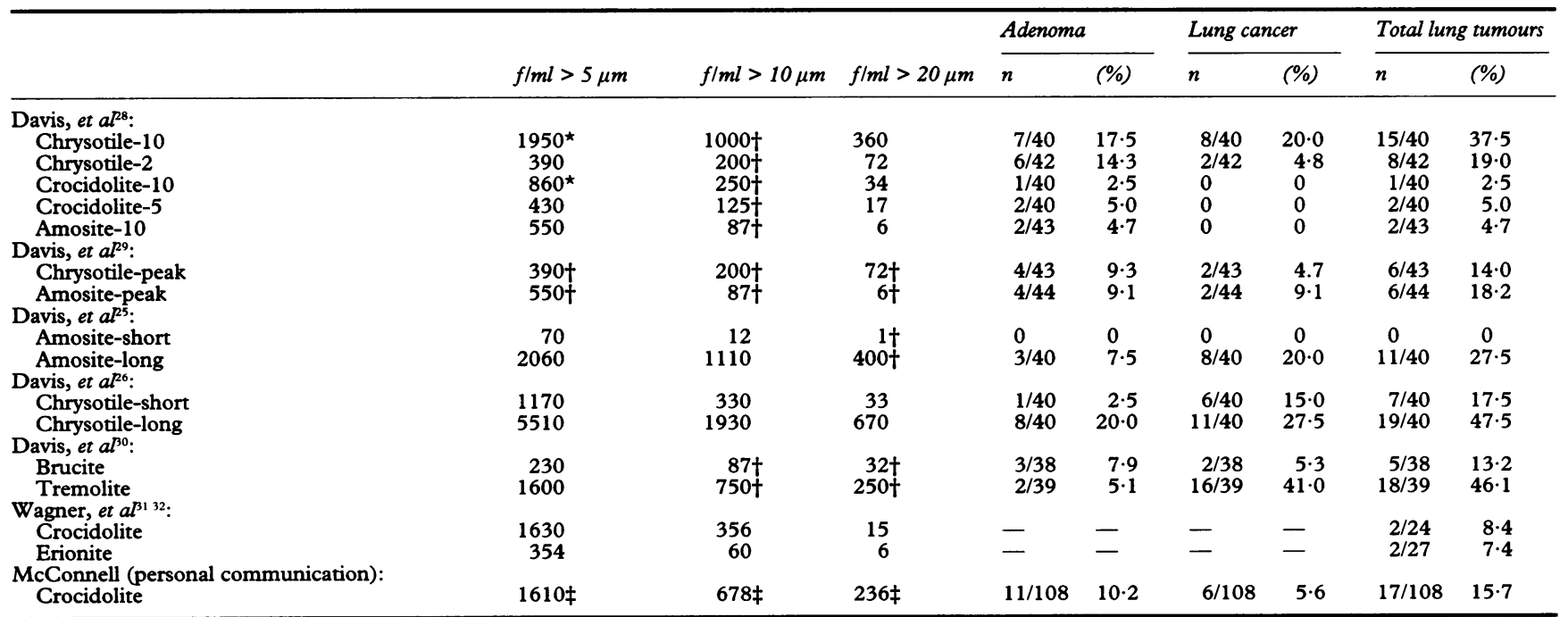

*Estimated by authors of paper with fibre size distribution data from scanning electron microscopy.

$\dagger$ Estimated for this analysis with technique used by the other authors or extrapolation from related studies in same laboratory.

$¥$ Based on analysis by transmission electron microscope. 


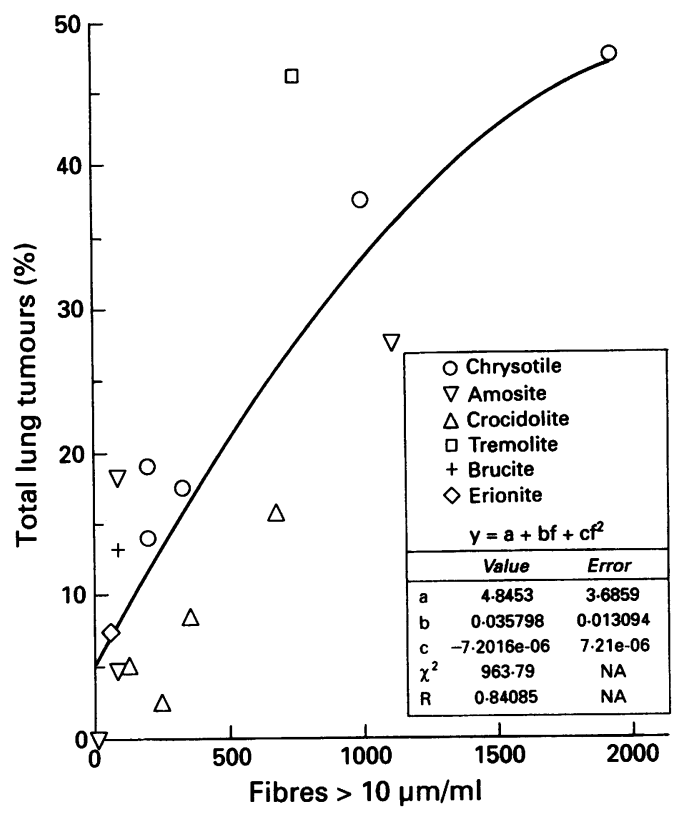

Figure 6 Total incidence of lung tumours in rats chronically exposed by inhalation to various mineral fibres as a function of the concentration of fibres $>10 \mu \mathrm{m}$ in length.

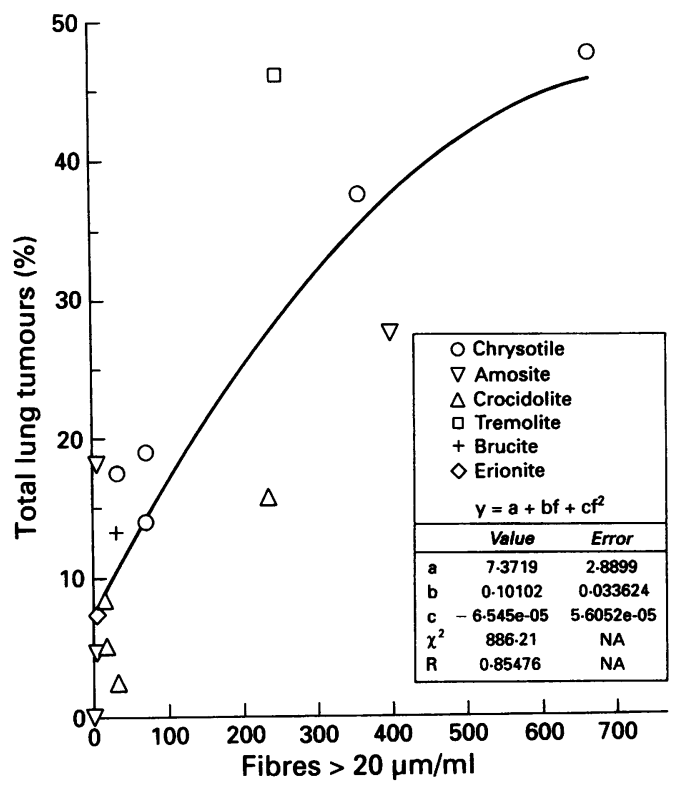

Figure 7 Total incidence of lung tumours in rats chronically exposed by inhalation to various mineral fibres as a function of the concentration of fibres $>20 \mu \mathrm{m}$ in length.

regression lines shown on these figures have higher regression coefficients than linear regression lines, which suggests a similarity to the dose-response relation for cancers caused by ionising radiation.

There seems to be little difference in lung tumour potency among amosite, brucite, chrysotile, and erionite. The crocidolite points may be about $50 \%$ below the curves, whereas the tremolite point may be about $50 \%$ higher. These are relatively small differences considering the uncertainties in determinations of fibre counts (or extrapolations in some cases) and substantial statistical uncertainties in the cases where none or only one or two tumours were reported. The best fits overall seem to be for the concentration of airborne fibres $>10$ or $>20 \mu \mathrm{m}$ long, consistent with my previous recommendation for an optimal cut off size for risk of lung cancer. ${ }^{27}$ The intercept between 0 and $5 \%$ is consistent with the small background (control animal) incidence in these studies. In any case, the fit for the $5 \mu \mathrm{m}$ cut off is not much worse than those for 10 or $20 \mu \mathrm{m}$, and it seems that the conventional occupational health exposure limit, with its phase contrast optical measurement technique and $5 \mu \mathrm{m}$ cut off size, provides a reasonable index of lung cancer risk for rats. Whether this conclusion applies to humans remains an open question, as is the question of what mechanism could account for the lack of any major influence on the composition, surface properties, and biopersistence of mineral fibres on risk of lung cancer in rats. The invocation (fig 4) by Pott of the one hit model suggests that any common biological response related to induction of lung cancer must take place before retention time differences emerge. ${ }^{24}$ One such possibility for an early key event in response to inhaled fibres is phagocytosis by epithelial cells. Brody et al showed that for rats chrysotile fibres that deposit preferentially at the bifurcations of small airways are taken up by underlying epithelial cells within hours of their deposition. ${ }^{5}$

Epithelial cells in the larger conductive airways of the rat lung have also been shown to ingest particles from the airway surface. ${ }^{10}$ The implications of uptake of such large particles in airways of human lungs on long term retention in bronchial airways was discussed by Fang et al. ${ }^{33}$ As noted previously, there is preferential deposition of fibres $>10 \mu \mathrm{m}$ long on bifurcations of large airways due to the interception mechanism. ${ }^{14}$ The biological responses that the fibres initiate within the epithelial cells at the bifurcations of airways in humans may then be promoted by other agents, such as cigarette smoke. Despite the enhanced surface deposition at bifurcations, the fibres that deposit there may be only a small fraction of those inhaled because the bifurcation deposits tend to be concentrated on very small portions of the lung surface. Being concentrated near limited areas of deposition, "hot-spots" within interstitial sites are consistent with the knowledge that a small fraction of inhaled chrysotile can have long retention times as clusters in lung tissue, as discussed by Churg. ${ }^{13}$ The similarity of longterm retention of previously deposited chrysotile and amphibole fibres in rats (fig 1) and humans (fig 3 ) suggests that the risks of lung cancer in humans are also proportional to the airborne concentrations of long fibres of all types of asbestos.

Fibre retention, translocation, and mesothelioma

Churg reported on associations between fibres retained in the lungs of asbestos miners and millers from Thetford in Quebec with the incidence of mesothelioma. ${ }^{13} \mathrm{He}$ concluded that the tremolite content in the lung tissue 
was closely associated with mesothelioma, whereas the chrysotile content was not. This conclusion was consistent with the results of a multivariate analysis reported by $\mathrm{McD}$ onald $e t$ $a l$, which indicated that two thirds of the cases of mesothelioma for this population could be attributed to long ( $>8 \mu \mathrm{m})$ amphibole fibres, including tremolite, but that the chrysotile itself made no significant contribution. ${ }^{34}$ These, and other epidemiological associations between a variety of biopersistent fibres in lungs and mesothelioma, lead to the conclusion that exposure to chrysotile fibre on its own, even the extraordinarily high exposures of the miners and millers in Quebec, have little if any role in the induction of mesothelioma, and that most of the 33 mesotheliomas known to have occurred in the cohort of $>11000$ Quebec asbestos workers were at least in part caused by their exposure to the small fraction of fibres in their worksites that were tremolite. The very long residence times of tremolite fibres in lung tissue suggests that the tremolite fibres were acting as promoters of mesothelial tumours, if not as a whole carcinogen. An important open question is whether fibres retained in parenchymal lung play a part in promoting mesothelial tumours, or whether they provide a good index for the presence of biopersistent fibres in or adjacent to mesothelial cell surfaces.

Results of the chronic rat inhalation tests with mineral fibres provide some relevant support for the hypothesis that inhaled chrysotile fibres by themselves pose relatively little if any risk for mesothelioma. Table 2 summarises the results of the chronic rat inhalation studies with mineral fibres and their induction of mesothelioma. In this table, I have separated

Table 2 Mesotheliomas produced by asbestos in chronic rat inhalation studies

\begin{tabular}{|c|c|c|}
\hline Type of Asbestos & Source & Tumours/animals \\
\hline 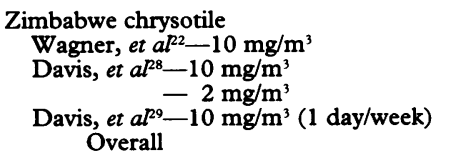 & $\begin{array}{l}\text { UICC } \\
\text { UICC } \\
\text { UICC } \\
\text { UICC }\end{array}$ & $\begin{array}{l}0 / 44 \\
0 / 44 \\
1 / 42 \\
0 / 43 \\
1 / 169(0 \cdot 6 \%)\end{array}$ \\
\hline 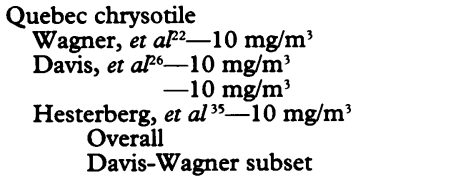 & $\begin{array}{l}\text { UICC } \\
\text { Short } \\
\text { Long } \\
\text { NIEHS }\end{array}$ & $\begin{array}{l}4 / 44 \\
1 / 40 \\
3 / 40 \\
1 / 69 \\
9 / 193(4 \cdot 7 \%) \\
8 / 124(6 \cdot 5 \%)\end{array}$ \\
\hline $\begin{array}{l}\text { Amphiboles } \\
\text { Wagner, et a }{ }^{2}{ }^{3} \text { : } \\
\text { Crocidolite }-10 \mathrm{mg} / \mathrm{m}^{3} \\
\text { Amosite-10 } \mathrm{mg} / \mathrm{m}^{3} \\
\text { Anthophyllite-10 mg/m } / \mathrm{m}^{3}\end{array}$ & $\begin{array}{l}\text { UICC } \\
\text { UICC } \\
\text { UICC }\end{array}$ & $\begin{array}{l}2 / 44 \\
0 / 46 \\
2 / 46\end{array}$ \\
\hline $\begin{array}{l}\text { Davis, et al }{ }^{\mathrm{l}} \text { : } \\
\text { Crocidolite- } 5 \mathrm{mg} / \mathrm{m}^{3} \\
\text { Crocidolite-10 } 10 \mathrm{mg} / \mathrm{m}^{3} \\
\text { Amosite }-10 \mathrm{mg} / \mathrm{m}^{3}\end{array}$ & $\begin{array}{l}\text { UICC } \\
\text { UICC } \\
\text { UICC }\end{array}$ & $\begin{array}{l}1 / 43 \\
0 / 40 \\
0 / 43\end{array}$ \\
\hline 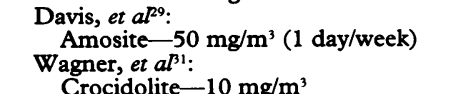 & UICC & $0 / 44$ \\
\hline $\begin{array}{l}\text { Davis, et al }{ }^{\circ 0}: \\
\text { Tremolite-10 } 10 \mathrm{mg} / \mathrm{m}^{3} \\
\text { Davis, et } \text { al }^{9} \text { : }\end{array}$ & Korea & $2 / 39$ \\
\hline $\begin{array}{r}\text { Amosite }-10 \mathrm{mg} / \mathrm{m}^{3} \\
-10 \mathrm{mg} / \mathrm{m}^{3}\end{array}$ & $\begin{array}{l}\text { Short } \\
\text { Long }\end{array}$ & $\begin{array}{l}1 / 42 \\
3 / 40\end{array}$ \\
\hline $\begin{array}{l}\text { McConnell (personal communication): } \\
\text { Crocidolite- } 10 \mathrm{mg} / \mathrm{m}^{3} \\
\text { Overall } \\
\text { Davis-Wagner subset }\end{array}$ & UICC & $\begin{array}{l}1 / 69 \\
13 / 520(2 \cdot 5 \%) \\
12 / 451(2 \cdot 7 \%)\end{array}$ \\
\hline
\end{tabular}

UICC = International Union Against Cancer, Lyon. NIEHS = National Institute of Environmental Health Sciences, Research Triangle Park, NC, USA. the studies into three groups. One is the amphiboles, which are associated with most of the mesotheliomas in exposed human populations. Another is chrysotile from Zimbabwe (formerly Rhodesia), which contains at least two orders of magnitude less tremolite than chrysotile from the Asbestos region in Quebec, and three orders of magnitude less tremolite than chrysotile from the Thetford region of Quebec (Pooley F, personal communication). The third group is the chrysotile from Quebec. It is clear that the essentially tremolite free chrysotile from Zimbabwe produces much less mesothelioma in rats than either Quebec chrysotile or the amphiboles. The results also suggest that tremolite is more potent than the other amphiboles, although it is clearly less potent in rats than erionite, a fibrous zeolite mineral, which produced 27 mesotheliomas in 28 rats (96\%) in the inhalation study of Wagner et al. ${ }^{31}$

If the risk of mesothelioma could be shown to be closely associated with the inhaled dose of airborne fibre that is biopersistent in lung tissue, then a research program might be able to establish a logical air sampling and analytical protocol for risk assessment. It might include: (a) a respirable dust pre-collector to keep oversized particles and fibres from obscuring the fibres of interest on the filter surface; $(b)$ laboratory downflow circulation through the horizontally mounted air sampling filter of a particle free solvent to dissolve chrysotile asbestos (and other soluble particulates), leaving biopersistent amphibole fibres undisturbed on the filter surface; $(c)$ transmission electron microscope analysis of the bivariate distribution of length and diameter and count of the biopersistent fibres on the filter or replica surface.

\section{Discussion}

The implications of the results discussed above should be considered in the design of new research studies. At the same time, many other research questions remain unresolved, including the ranges of fibre length and diameter that determine translocation pathways, retention times at critical sites, and biological responses within cells. The roles of the cellular products stimulated by the presence of the fibres within the cells, and of the cellular products discharged from the cells, need further investigation. The nature of any DNA transformations induced by the fibres or the reaction products that may be critical to the development of tumours also need to be investigated. For the present, it is encouraging that the state of the knowledge about the health risks associated with chrysotile and other mineral and vitreous fibres has advanced to the point where we have (a) a much better ability to pose the key questions; and (b) more powerful techniques to answer them.

This research was supported by Grant ES00881, and is part of a center program supported by Grant ES00260, both from the National Institute of Environmental Health Sciences. This work was presented as "The fate of aerosol particles in the airways", at a symposium in honour of the retirement of Dr Willi Stahlhofen; Frankfurt/Main; 25, 26 March 1994. 
1 Gurman JL, Lippmann M, Schlesinger RB. Particle deposition in replicate casts of the human upper tracheobronchial tree under constant and cyclic inspiratory flow: I Experimental. Aerosol Science and Technology 1984;3:245-52.

2 Lippmann M, Schlesinger RB. Interspecies comparisons of particle deposition and mucociliary clearance in tracheoparticle deposition and mucociliary clearance in tracheo-
bronchial airways. $\mathcal{J}$ Toxicol Environ Health 1984;13: 441-69.

3 Briant JK, Lippmann $M$. Particle transport through a hollow canine airway cast by high-frequency oscillatory ventilation. Exp Lung Res 1992;18:385-407.

4 Briant JK, Lippmann M. Aerosol bolus transport through a hollow cast by steady flow in different gases. Aerosol Science and Technology 1993;19:27-39.

5 Brody AR, Hill LH, Adkins B Jr, O'Connor RW. Chrysotile asbestos inhalation in rats: deposition pattern and reaction of alveolar epithelium and pulmonary macrophages. Am Rev Respir Dis 1981;123:670-9.

6 Brody AR, Roe MW. Deposition pattern of inorganic particles at the alveolar level in the lungs of rats and particles at the alveolar level in the lun
mice. Am Rev Respir Dis 1983;128:724-9.

7 Warheit DB, Hartsky MA. Species comparisons of alveolar deposition patterns of inhaled particles. Exp Lung Res 1990;16:83-99.

8 Stirling C, Patrick G. The localisation of particles retained in the trachea of the rat. $\mathcal{F}$ Pathol 1980;131:309-20.

9 Gore DJ, Patrick G. A quantitative study of the penetration of insoluble particles into the tissue of the conducting airways. Ann Occup Hyg 1982;26:149-61.

10 Gehr P, Geiser M, Im Hof V, Schuerch S, Cruz-Orive LM. Serological estimation of particle retention and clearance in the intrapulmonary conducting airways of clearance in the intrapulmonary conducting airways of
the hamster lungs. Fournal of Aerosol Science 1990; the hams

11 Brody AR, Yu CP. Particle deposition at alveolar duct bifurcations. In: Crapo JC, Miller FJ, Smolko ED, Graham JA, Hayes AW, eds. Extrapolation of dosimetric relationships for inhaled particles and gases. New York: Academic Press, 1989;91-9.

12 Lippmann $M$, Timbrell V. Particle loading in the human ung - human experience and implications for exposure limits. 7 Aerosol Med 1990;3:S155-68.

13 Churg A. Deposition and clearance of chrysotile asbestos. Ann Occup Hyg 1994;38:625-33.

14 Sussman RG, Cohen BS, Lippmann M. Asbestos fiber deposition in a human tracheobronchial cast. II. deposition in a human tracheobronchial

15 Morgan A, Holmes A, Davison W. Clearance of sized glass fibers from the rat lung and their solubility in vivo. Ann Occup Hyg 1982;25:317-31.

16 Churg A, Tron V, Wright JL. Effects of cigarette smoke exposure on retention of asbestos fibers in various morphologic compartments of the guinea pig lung. $A m \mathcal{F}$ Pathol 1987;129:385-93.

17 Oberdörster G, Morrow PE, Spurny K. Size dependent lymphatic clearance of amosite fibers in the lung. Ann Occup Hyg 1988;32:149-56.

18 Allison AC. Mechanisms of macrophage damage in relation to the pathogenesis of some lung diseases. In: Brain JD, Proctor DF, Reid LM, eds. Respiratory defense JD, Proctor DF, Reid LM, eds. Respiratory defe

19 Timbrell V. Fibers and carcinogenesis. Fournal of the Occupational Health Society of Australia 1983;26:347-69.
20 Oberdörster G, Ferin J, Finkelstein J, Soderholm S, Gelein R. Mechanistic studies on particle-induced acute and chronic lung injury. In: Masuda S, Takahashi $\mathrm{K}$, eds. Aerosol-science, industry, health and environment. Vol II. Oxford: Pergamon Press, 1990:1229-33.

21 Lippmann M. Particle deposition and accumulation in human lungs. In: Dungworth $\mathrm{DL}$, Mauderly $\mathrm{J}$, Oberdörster HG, eds., Toxic and carcinogenic effects of solid particles in the respiratory tract. Washington: ILSI solid particles in the resp

22 Wagner JC, Berry G, Skidmore JW, Timbrell V. The effects of the inhalation of asbestos in rats. $\mathrm{Br} \mathcal{F}$ Cancer 1974;29:252-69.

23 HEI-AR. Asbestos in public and commercial buildings: a literature review and synthesis of current knowledge. Cambridge, MA: Health Effects Institute-Asbestos Research, 1991: $317 \mathrm{pp}$.

24 Pott F. Asbestos use and carcinogenicity in Germany and a comparison with animal studies. Ann Occup Hyg 1994; 38:589-600.

25 Davis JMG, Addison J, Bolton RE, Donaldson K, Jones $A D$, Smith T. The pathogenicity of long versus short fiber samples of amosite asbestos administered to rats by inhalation and intraperitoneal injection. $B r \mathcal{F}$ Exp Patho 1986;67:415-30.

26 Davis JMG, Jones $\mathrm{AD}$. Comparisons of the pathogenicity of long and short chrysotile asbestos in rats. $B r F E x p$ Pathol 1988;69:717-37.

27 Lippmann M. Asbestos exposure indices. Environ Res 1988;46:86-106.

28 Davis JMG, Beckett ST, Bolton RE, Collings $P$, Middleton AP. Mass and number of fibers in the pathogenesis of asbestos-related lung disease in rats. $\mathrm{Br} \mathcal{f}$ Gancer 1978;37:673-88.

29 Davis JMG, Becket ST, Bolton RE, Donaldson K. The effects of intermittent high asbestos exposure (peak dose levels) on the lungs of rats. Br F Exp Pathol 1980;61: 272-80.

30 Davis JMG, Addison J, Bolton RE, Donaldson K, Jones AD, Miller BG. Inhalation studies on the effects of tremolite and brucite dust in rats. Carcinogenesis 1985; 6:667-74.

31 Wagner JC, Skidmore JW, Hill RJ, Griffiths DM. Erionite exposure and mesotheliomas in rats. $B r f$ Cancer 1985 51:727-30.

32 Wagner JC. Biological effects of short fibers. In Proceedings of the VIIth international pneumoconiosis conference, part II. Washington: DHHS 1990:835-9. (NIOSH Publ No 90-108.)

33 Fang CP, Wilson JE, Spektor DM, Lippmann M. Effect of lung airway branching pattern and gas composition on particle deposition in bronchial airways. III. Experimental studies with radioactively tagged aerosol in human and canine lungs. Exp Lung Res 1993;19:377-96.

34 McDonald JC, Sebastien P, McDonald AD, Case B Epidemiological observations on mesothelioma and their implications for non-occupational exposure. In: Bignon J Peto J Saracci $R$ eds. Non-occupational exposure to mineral fibres. Lyon: International Agency for Research mineral fibres. Lyon: International Agency for Resea
on Cancer, 1989;420-7. (IARC Sci Publ No 90.)

35 Hesterberg TW, Miller WC, McConnell EE, Chevalier J, Hadley JG, Bernstein DM, et al. Chronic inhalation toxicity of size-separated glass fibres in Fischer 344 rats. Finden Appl Toxicol 1993;20:464-76.

\section{Correspondence and editorials}

Occupational and Environmental Medicine welcomes correspondence relating to any of the material appearing in the journal. Results from preliminary or small scale studies may also be published in the correspondence column if this seems appropriate. Letters should be not more than 500 words in length and contain a minimum of references. Tables and figures should be kept to an absolute minimum. Letters are accepted on the understanding that they may be subject to editorial revision and shortening.

The journal also publishes editorials which are normally specially commissioned. The Editor welcomes suggestions regarding suitable topics; those wishing to submit an editorial, however, should do so only after discussion with the Editor. 